DEPARTMENT OF THE INTERIOR

$\rightarrow$

U.S. GEOLOGICAL SURVEY

\title{
OBSERVATIONS IN MONTEREY CANYON AND FAN VALLEY USING THE SUBMERSIBLE ALVIN \\ AND A PHOTOGRAPHIC SLED
}

by

S.L. Eittreim ${ }^{1}$, R. W. Embley ${ }^{2}$, W. R. Normark ${ }^{1}$

H.G. Greene ${ }^{1}$, C. M. McHugh ${ }^{3}$, and W.B.F. Ryan ${ }^{3}$

Open-File Report 89-291

This report is preliminary and has not been reviewed for conformity with U.S. Geological Survey editorial standards or with the North American Stratigaphic Code. Any use of trade, product, or firm names is for descriptive purposes only and does not imply endorsement by the U.S.

Government.

${ }^{1}$ U.S. Geological Survey, Menlo Park, CA 94025

${ }^{2}$ National Oceanic and Atmospheric Administration,

Hatfield Marine Science Center, Newport, OR 97365

${ }^{3}$ Lamont-Doherty Geological Observatory, Palisades, N.Y. 10964 


\section{TABLE OF CONTENTS}

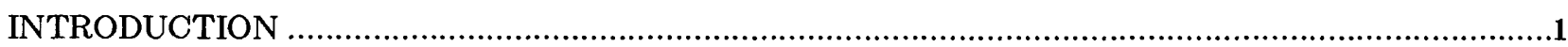

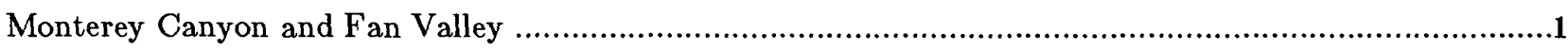

Dive Synopses

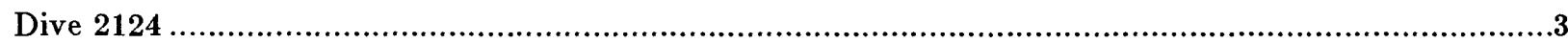

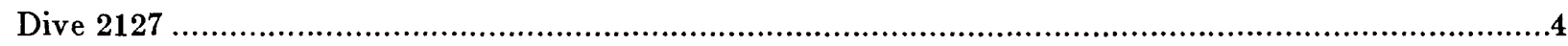

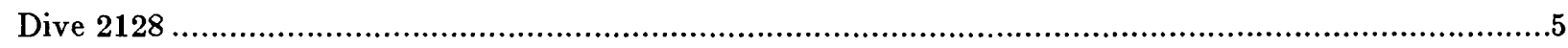

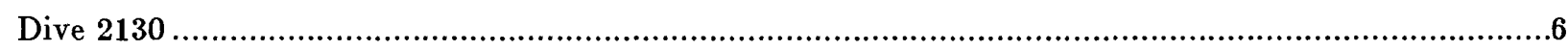

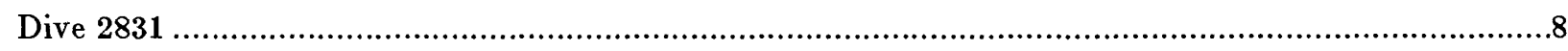

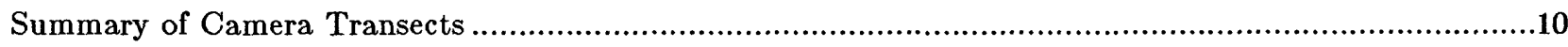

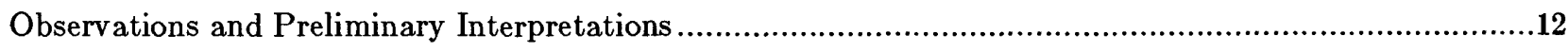

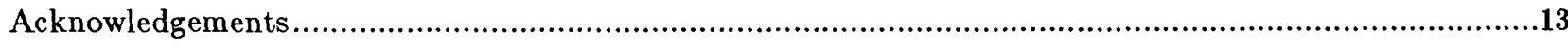

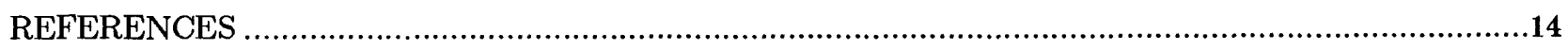

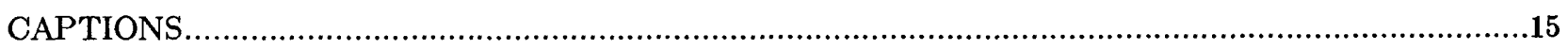

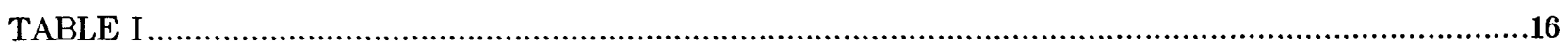




\section{INTRODUCTION}

In October-November 1988 a series of 10 research dives using DSRV ALVIN were conducted along the axis of the Monterey canyon-fan valley system. Of those 10 dives, 4 were carried out by the National Geographic Society for biological studies involving deep-water shark behavior. One dive was for biologic studies of the Monterey Bay Aquarium (MBA) and the Monterey Bay Aquarium Research Institute (MBARI). The remaining five dives, whose locations are shown in Figures 1 and 2, are the subject of this report. The two observers' seats on each of these dives were occupied by a geologist and a biologist. The biological studies were conducted by a group of researchers at MBA, MBARI, and Moss Landing Marine Labs and will be reported on elsewhere. We report here on the geological observations and the benthic biological observations that relate to geologic processes of canyon formation and maintenance.

The purpose of this report is to document the location of the work and the sample collection as well as to provide a basis for planning future studies. We include brief synopses of each of the five dives, maps of submersible dive tracks, and principal observations along these tracks. In addition to the information from ALVIN observations, we include observations from a number of camera bottom-sled tows made along 2- to 8-km-long tracks during the non-dive time aboard the mothership, the R/V ATLANTIS II. The interpretations from these observations are preliminary and limited as detailed analyses of samples and photo images is in progress.

Samples of sea-floor muds were obtained using 30-cm core tubes (up to six per dive) pushed in to the sediment with one of ALVIN's manipulators. More consolidated sediments and rocks were sampled using the manipulator claw and biological nets. Color photographs from the bow-mounted ALVIN camera and video tapes from both the bow-mounted black and white silicon-intensified target camera and the arm-mounted color camera were obtained regularly during times on bottom with ALVIN. An unexpected finding was the occurrence of benthic biological communities apparently suported by organic-rich seeps along the walls and floor of the seavalley. The first observation of this phenomeon was made on dive 2123 by observers E. Kristoff (NGS) and E. Clark (U. of Maryland). Collection of samples of these lifeforms as well as their mud substrates was made on three separate dives using ALVIN's manipulator.

\section{Monterey Canyon and Fan Valley}

The Monterey canyon heads near the surf zone in central Monterey Bay and extends across the continental shelf and slope and, through its major fan valley system, extends to its outer depositional lobes that lie more than $400 \mathrm{~km}$ from the base of the continental slope in water depths exceeding $4700 \mathrm{~m}$ (Normark et al., 1985; EEZ-SCAN 84 Scientific Staff, 1986). At the head of the canyon in water depths shallower than $500 \mathrm{~m}$, sediment mass failures are common, as evidenced by frequent collapse of the outermost pilings of the Moss Landing pier (Shepard, 1973). The base of the continental slope near $3000 \mathrm{~m}$ water depth is generally considered the boundary between the eroded rock-walled canyon of the continental shelf/slope terrain and the fan valley, which has locally been deeply eroded in to the sediments of Monterey fan (Shepard and Dill, 1966). The Monterey canyon axis and its fan valley extension, along which there is a continuous convex-upward profile, are the most distinctive morphologic feature of the central California continental margin.

Although the morphometric impression is that Monterey canyon is the dominant source of sediment to the fan itself, the true apex of the fan lies farther north where the Ascension canyon system debouches at water depths near $2900 \mathrm{~m}$. Available seismic-reflection profiles show also that the thickest section of sediment on Monterey fan (more than $2.5 \mathrm{~km}$ ) is at the 
base of the slope under the large, leveed fan valley that extends from Ascension canyon (Wilde et al., 1978). With the exception of local topographic depressions, the sediment section rarely exceeds $1.5 \mathrm{~km}$ even under the upper Monterey fan along the base of the continental slope (Normark et al., 1985). Normark (1970) showed that the prominent western levee of the present Monterey fan valley west of $123^{\circ} \mathrm{W}$ longitude is related to the valley extending from the Ascension canyon system and that the valley extending from Monterey canyon has captured this pathway only recently in the fan history. The piracy event that he describes has left the Ascension valley as a hanging tributary to the deeply incised Monterey valley (Figures 1 and 2) and left the previous continuation of the valley extending from Monterey canyon as a hanging distributary, which Normark (1970) named Monterey East valley.

Research to date has only speculated on the sequence of events during the growth of Monterey fan (Normark et al., 1985). The actual timing of the development of Ascension valley, the channel piracy event, and the downcutting that formed the present deeply-eroded valley extending from Monterey canyon are not known. The age of the oceanic crust upon which the fan has formed is late Oligocene, based on the interpretation of magnetic anomaly patterns (Atwater, 1970). Normark et al., (1985) note that the fan sedimentation could have begun as early as late Oligocene or early Miocene, shortly after the Farallon-Pacific spreading center was abandoned along the base of the continental slope. Available sedimentation rates, however, show that the entire 1-km section of sediment underlying the upper fan levees could have been deposited in 5 my or less (Brunner and Normark, 1985). The sedimentation rates they determined are only for the Holocene section, which is thought to represent a period of relatively slow deposition during the high stand of sea level. Thus, if sedimentation during low sea-level stands was substatially greater than for the Holocene, the entire fan sequence could be as young as Pleistocene.

One of the objectives of the dive program was to sample the oldest of sediment exposed in the eroded part of the present Monterey fan valley. The greatest erosional relief of the valley is between the base of the slope near $3000 \mathrm{~m}$ water depth and just beyond the Monterey meander (Figure 2). The pronounced meander loop in the Monterey fan valley, discovered by Shepard (1966), is a horshoe-shaped meander approximately $7-\mathrm{km}$ in diameter between axial depths of $3360 \mathrm{~m}$ to $3500 \mathrm{~m}$. Figure 2 shows the bathymetry of the meander area as mapped with the SEABEAM swath-mapping bathymetric system of the NOAA ship SURVEYOR in 1983 (Eittreim, Embley, and Normark, 1983).

Three of the five dives reported here were conducted in the meander area (Figure 2), and two were located in the steep-walled canyon at shallower depths (Figure 1). Bottom-camera tows were made along and across the valley axis and its walls and across the adjacent Monterey fan surface and continental slope area (Figure 2). The principal scientific objectives of the dives were to investigate, in reconnaissance fashion: (a) the modern erosional/depositional processes of the valley floor and (b) the lithology and age of eroded and outcropping valley-wall strata. Of prime interest are the rates of sedimentary proceses on all time scales involved in the canyon's maintenance. The occurrence of sediment failures at the canyon head suggest at least the possibility of active events on an approximately yearly time scale. Existing knowledge suggests that Monterey fan may be as old as $25 \mathrm{Ma}$ (Wilde, Normark, and Chase, 1978). The upper, approximately one third, of the strata of the fan have been incised by the fan valley, and therefore, is accessible by sampling the valley walls. 


\section{Dive Synopses}

Dive No. 2124

Observers: W. Normark and G. Cailliet

Pilot: T. Tengdin

Dive 2124 traversed the most deeply eroded section of the main Monterey fan valley, where its axis reaches depths of $3580 \mathrm{~m}$, south of its confluence with the tributary Ascension fan valley (Figure 3). The primary geologic objectives were to (1) cross the entire floor of the valley to evaluate the recency of turbidity-current flow within this part of the valley, (2) obtain samples from the western wall of the valley to determine the biostratigraphic age and sediment accumulation rate for the upper third of the fan sequence exposed at this site, and (3) document the evidence for erosion and mass-wasting that are thought to characterize this section of the valley.

The dive activities consist of four basic components: touchdown over the lower east wall of the valley, transect of the valley floor, sampling at the base of the west wall of the valley, and transect of the west wall from the valley floor to near the levee crest.

The initial phase of the dive was over the westward slope of the lowest terrace level on the eastern side of the Monterey fan valley (Figure 3). Most of the time in this area was spent in waiting for thick sediment clouds to disperse to allow photographic and sampling operations. During the few brief moments when the sediment cloud did not obscure the valley floor, we observed two separate mound features but were unable to sample (or even relocate for sampling) either of them. Much of the sediment was probably stirred up by the movement of the submarine, but during a short traverse upvalley, parallel to the terrace slope, we were traveling alongside a sediment cloud that was coming from another source, perhaps natural turbidity of the downvalley currents that seemed to characterize much of our time on the bottom during this dive.

After nearly one hour on the bottom along the east side of the valley, no samples of mounds that might be formed of talus blocks from east-wall terraces could be obtained because of the difficulty of working in the sediment clouds. At this point, we began our traverse on course $315^{\circ}$ to cross the main valley floor (Figure 3). Photographic surveying was the primary documentation of this segment of our dive. The valley floor is covered by an unconsolidated muddy layer that shows extensive bioturbation features and is covered by a high density of organisms, including worms, holothurians, fish and some stalked organisms. The sediment was very easily put in suspension, so every time we tried to stop, the sediment cloud would overtake the submarine. The one core sample attempted from the valley floor (sample 1, Figure 3) was unsuccessful because the sediment was too unconsolidated to remain in the core barrel as it was moved from the sea floor to the basket.

The base of the west wall of the valley is a vertical scarp about $7 \mathrm{~m}$ high and relatively straight for at least $50 \mathrm{~m}$ (in a traverse upvalley). We obtained samples from the lowest meter of the exposed scarp by scraping the consolidated sediment into a scoop net and by retrieving a piece of fresh talus thought to have come from about one-half meter up the scarp. The wellbedded sediment exposed along the scarp is generally planar for the distance of our upvalley traverse and is too consolidated for the push core samplers. A rounded mound about 1-m high and $2 \mathrm{~m}$ from the base of the scarp on the valley floor was soft enough to sample with the base of the push core and was shown to be semi-indurated gray clay; thus, it is probably a piece of weathered talus from higher up on the valley wall. 
The last major activity during the dive was to traverse the west wall of the valley, which is nearly $350 \mathrm{~m}$ high in this area. The lower part of the wall consists of vertical to near-vertical scarps separated by sloping (as much as $30^{\circ}$ ) terrace surfaces covered by unconsolidated sediment and large talus blocks as much as $5 \mathrm{~m}$ across. The uppermost vertical scarp is $38 \mathrm{~m}$ high and the top (at $3484 \mathrm{~m}$ ) is nearly $100 \mathrm{~m}$ above the deepest part of the valley floor along the traverse made during this dive. Above this scarp, the wall slopes rarely exceed $10^{\circ}$ and talus blocks are much less common. The traverse terminated at a depth of $3245 \mathrm{~m}$ over gentle slopes of a few degress with an unconsolidated sediment cover. The sediment cover on the terraces and upper part of the west wall is not as easily disturbed as is the sediment on the valley floor.

In summary, dive 2124 showed conclusive evidence for the erosional cutting of at least the lower $100 \mathrm{~m}$ of the valley relief. There is no evidence for turbidity-current activity in the recent past; no coarse sediment or sediment bedforms were observed on the valley floor along the transect. The level of biologic activity (population density) is markedly higher on the valley floor than higher up on the walls or levee crest.

The sediment samples from the base of the wall have been submitted for paleontological age determination, but no results are available at this time.

Dive 2127

Observers: S. Eittreim and J. Watanabe

Pilot: P. Tibbetts

Dive 2127 began on the inside curve of the large southward-protruding meander in Monterey seavalley (Figures 2 and 4). The objectives of the dive were to traverse across the fan valley floor from wall to wall, and then climb the steep west wall which forms the outside of the meander bend, making visual, video, and camera observations and sampling the seafloor at points of interest. The depth at ALVIN touchdown, on the inside wall of the meander valley, was $3397 \mathrm{~m}$.

From the touchdown point, we traversed the mud-covered valley floor on a course of 270 degrees. Three and possibly four terraces were crossed descending the east wall, the first of which was $29 \mathrm{~m}$ high. The next two terraces dropped $4 \mathrm{~m}$ and $2 \mathrm{~m}$, respectively. At the base of the final terrace, the deepest point of the valley floor $(3482 \mathrm{~m})$ was reached. The width of the inner valley floor below the lowermost terrace is estimated to be $100 \mathrm{~m}$ from east to west (Figure 4).

The valley floor was covered with highly flocculant and bioturbated mud, populated with small tube worms, foraging holothurians, large (20-cm diameter) apricot-colored sea anemones, rat-tailed fish and other organisms. This mud was very easily stirred up to produce clouds of turbid water whenever the sub maneuvered close to bottom or attempted to sample the seafloor. One unsuccessful attempt was made to sample a piece of drift kelp in the deep valley floor.

The greatest depth, $3482 \mathrm{~m}$, persisted all the way to the base of the west wall. This wall was an abrupt, vertical face which sharply delineated the edge of the valley floor muds (Figure 5). The wall was thickly populated with a large variety of organisms and it appeared banded, suggestive of horizontal layering. After encountering the west wall, we turned northward and followed along its base (Figure 4). After traversing about $100-200 \mathrm{~m}$, the steep west wall gave way to a moderately sloping valley wall that appeared to be a mud-covered talus or debris slope with many debris blocks. Attempts to sample the blocks showed that they consisted of semiconsolidated mudstone as they broke apart when gripped by ALVIN's manipulator arm. The slope of this talus-debris wall was approximately 30 degrees. 
After driving north along the wall for $200 \mathrm{~m}$, we turned east away from the wall base to sample typical muds of the deepest part of the valley floor (samples 1a, b, c; Figure 4). Three plastic core pipes, each about $40 \mathrm{~cm}$ long were pushed in to the mud by ALVIN's manipulator arm. This resulted in one $30 \mathrm{~cm}$ core of soft muds and two shorter cores of about $10 \mathrm{~cm}$ each.

Four hundred meters to the north of the core sample site, we turned west to climb the slope of the wall, now between about 30-45 degrees. At about $30 \mathrm{~m}$ above the valley floor, on what appeared to be a talus or debris pile, a small colony of clams (about six individuals) was encountered, associated with a gray-black discoloration of the otherwise brown surface mud. A sample of the clams and the sediment was obtained for analysis. This colony apparently marked a seep of organic-rich fluids from the underlying sediment. Climbing farther up the sloping west wall, ALVIN encountered horizontally bedded, poorly-consolidated sediment outcropping on the seafloor, with a slope of approximately 45 degrees. After climbing farther to $3405 \mathrm{~m}$, about $80 \mathrm{~m}$ above the valley floor, the dive was terminated because a technical problem developed with the carbon dioxide scrubber system.

In summary, this dive showed that the fan valley floor at this point was completely covered with fine muds, revealing a relative quiescence, at least on some significant-length time scale. Whether this time scale is measured in weeks, months, or $10^{3}$ years is unknown at present. Direct evidence of major erosional downcutting was shown by the vertical wall of bedded strata along part of the valley-wall base. The evidence for localized organic seeps that support colonies of clams among the talus blocks of the west wall is perhaps one of the most significant observations from this dive.

A total of seven mud samples from two locations were obtained on this dive: one on the valley floor, and one on the lower valley wall at the site of the clam colony and presumed organic seep.

Dive 2128

Observers: H. G. Greene and C. Harrold

Pilot: T. Tengdin

Bottom was first encountered at 9:20 a.m. in a water depth of $1987 \mathrm{~m}$ on the east side of the Monterey canyon floor (Figure 1). The intent of this dive was to cross the Monterey canyon floor, sampling both walls, cross again back to the intersection of Carmel canyon, progress up the Carmel canyon and sample the canyon's northeast wall (Figure 6). Total time on bottom was 5 hours and 20 minutes. We travelled generally northeast $\left(030^{\circ}\right)$ across mud to sandy mud bottom, strongly rippled and peppered with anomalously clean, white granodiorite boulders of the Monterey Mass (Greene, 1977). During this northeast traverse, the bottom deepened to $1996 \mathrm{~m}$, then shallowed as we approached a steep eastern wall at a depth of $1970 \mathrm{~m}$. Apparently ALVIN landed on the eastern margin of the channel and traversed sub-parallel to this margin until encountering the wall. We spent 25 minutes examining and sampling the wall which was found to be composed of banded metamorphic rocks.

After sampling, we headed north $\left(339^{\circ}\right)$ where the canyon wall appeared more layered, the rocks stepped down to the north and east from $1951 \mathrm{~m}$ to $1971 \mathrm{~m}$ and the seafloor flattened out to a sandy-mud bottom. On a general northerly heading we continued to about the mouth of Carmel canyon.

We turned west $\left(\sim 300^{\circ}\right)$ across the Monterey canyon axis at $1971 \mathrm{~m}$ depth. The canyon floor was highly rippled and contained a few sediment covered boulders. The western side of the canyon was approached at $1964 \mathrm{~m}$ depth where rocks and sedimentary layers are exposed. 
We climbed to $1956 \mathrm{~m}$ to examine a large (10's of meters in diameter) boulder with abutting flat lying mudstone layers. The boulder appeared to be granitic (unable to sample) and probably is out of place. We continued to climb to $1953 \mathrm{~m}$ where another well-rounded boulder was found again abutted with flat-lying, well-layered mudstones. The boulder was very hard; we were unable to obtain samples from either boulder or mudstone layers. The area appears to be a landslide remnant.

At a depth of $1956 \mathrm{~m}$ we turned to $029^{\circ}$ for return traverse across the main Monterey canyon floor. The bottom was relatively smooth, with some subtle ripples, much man-made debris and wood. In $1974 \mathrm{~m}$ of water, we entered into a white, granodiorite boulder field with a large tree trunk and ripples.

We crossed previous traverse track at a depth of $1979 \mathrm{~m}$ and continued on a bearing of about $125^{\circ}$. The bottom dropped off to $1984 \mathrm{~m}$. Large flat slabs of brown coated rocks were encountered at a depth of $1982 \mathrm{~m}$ prior to re-encountering the east wall of Monterey canyon.

At a depth of $1981 \mathrm{~m}$, a steep cliff exposed crumbly chunks of sandstone or mudstone. We then proceeded to ascend the cliff face. The face of the outcrop was jointed and fractured, very hard (unable to obtain a sample), probably metamorphic rock with brown phosphatic coating.

At a depth of $1965 \mathrm{~m}$ a rock outcrop was observed that appears to be granitic. We continued upslope through sand chutes and fractures in hard rocks that were impossible to break loose to sample. We lifted off bottom at 2:40 p.m., at a depth of $1942 \mathrm{~m}$.

In summary this dive showed that the eastern wall of Monterey canyon near the intersection of Carmel canyon is a steep, hard rock cliff composed of well consolidated sandstone and metamorphic rocks. The western wall is not as steep and appears to be composed of landslide debris that is presently being eroded. The canyon floor is composed of rippled sands suggestive of strong current action. Clean, white angular boulders of granite encountered on the canyon floor appear to be recent deposits transported to this site by a landslide further upcanyon. Greene (1977) mapped an area of mass wasting in the granodiorite porphyry exposed along the eastern walls of Monterey canyon, near the intersection of Carmel canyon, and these boulders could have come from this location.

Dive 2130

Observers: R. Embley and F. Rentschler

Pilot: P. Hickey

Dive 2130 was located in Ascension valley at a prominent downdrop in the thalweg about $8 \mathrm{~km}$ from its intersection with Monterey valley (Figures 2 and 7 ). The primary objectives of the dive were: (1) to locate and do concentrated sampling, photography and observations of seep communities; and (2) to examine and sample outcrops on both the east-west channel walls, and the westward-facing slope that was thought to be an analogue to a rapid or waterfall of subaerial rivers. ALVIN began its descent over the north wall of the valley. A mid-water transit to the south during the descent positioned the submersible on the north side of the valley floor during its final approach to the seafloor. At 10:20 a.m., ALVIN landed on the seafloor near the base of the north wall at $3408 \mathrm{~m}$. The valley floor was covered with a soft mud over which holothurians foraged. A traverse to the north began and a subtle, low-lying outcrop of friable mudstone was encountered and sampled at a depth of $3397 \mathrm{~m}$ (Station 1).

ALVIN departed Station 1 heading north and after $50 \mathrm{~m}$ encountered an extensive vertical 
walled exposure of mudstone. A core sample and chunks of the mudstone were recovered here at a water depth of $3391 \mathrm{~m}$ (Station 2; Figure 7). After sampling, ALVIN began moving east along the south-facing slope. The outcrops exhibited distinct layering up to $0.5 \mathrm{~m}$ in thickness and distinct vertical joints that appeared to intersect the layers at about $90^{\circ}$. The downslope movement of the blocks formed by these intersecting planes left distinct reetrants in the wall of the canyon. The mudstone surface appeared to have an extensive network of boreholes made by organisms and had a "swiss-cheese" appearance. Large sessile organisms were observed infrequently on the wall including a cluster of large sponges at one location farther east along the wall. Several notches formed by the intersecting joints were observed. Some had talus in them and some were talus-free.

At a water depth of $3386 \mathrm{~m}$, ALVIN turned and began a traverse up the wall. At a depth of $3385 \mathrm{~m}$ a section of wall was encountered where a recent spalling off of the outer oxidized layer exposed the olive-colored clay beneath. There was a striking contrast between the older, brownish colored wall covered with small sessile organisms and the recently exposed, olive-colored section that was relatively devoid of colonizing sessile organisms. The traverse up the wall ended at a water depth of $3348 \mathrm{~m}$. At this point, ALVIN turned south and began a mid-water traverse to the south side of the valley.

Touchdown on the valley floor was in a water depth of $3411 \mathrm{~m}$. The southward traverse continued across the floor of the valley. The bottom was similar in appearance to the original landing site. At $3409 \mathrm{~m}$ depth there was a slight increase in slope upwards and $30 \mathrm{~m}$ farther on there was a significant increase in the density of the small $(5-15 \mathrm{~cm}$ ) stalked organisms (mostly tubeworms) that had been observed sporadically on the valley floor. The overall impression was of a field of tall grass (Figure 8). Clam shells and several clusters of live clams were encountered at $3405 \mathrm{~m}$ depth where ALVIN stopped for sampling and observation of the area. The clam clusters were lying in shallow depressions in areas that were relatively barren of the dense stalked organisms. Numerous trails in the area were probably made by predators (including an octopus seen when the area was approached) and/or by the clams themselves. A net sample containing two intact live clams (Figure 9) and several fragments was recovered here. Other samples at the site included mud samples recovered in the net, a core sample at the clam site, and another core taken to sample one of the worm tubes a few meters from the clam site.

After 5 minutes on Station 3, ALVIN departed and followed the $3405 \mathrm{~m}$ contour eastward to test the idea that the seeps might be controlled by geologic horizons exposed by the downcutting event or events that created the present valley system. A dense community of stalked organisms was observed on the traverse and at least three additional clam clusters were photographed. The dense zone of stalked organisms terminated after a traverse of about $100 \mathrm{~m}$. ALVIN then turned south to continue the transect up the south wall. Several patches of the worm tubes were observed along this traverse. The basal outcrop of the south wall was reached at a depth of $3386 \mathrm{~m}$. A degraded outcrop zone was sampled at Station 4 (Figure 7).

An eastward traverse was then begun along the base of the wall. The wall was inclined at an angle of 30 to 60 degrees with infrequent subtle outcrops. The traverse ended at $3383 \mathrm{~m}$ depth when ALVIN turned back into the canyon to examine a concentration of shells. After manuvering down in to the valley floor $(3396 \mathrm{~m}$ ), a large cluster of (probable) Solemya clam shells came into view. The clams were concentrated precisely at the base of the valley wall and the shells had been colonized by white-stalked anenomes up to about $10 \mathrm{~cm}$ in length. An ALVIN-generated mud cloud obscured the site and ended the observations. The eastward traverse continued along the base of the wall and sporadic outcrops and clam shells were observed along the remainder of this traverse. Farther along the base of the wall a clump of possible dead tube worms and a concentration of clam shells were noted. No live clams were confirmed although some were possibly sighted along this traverse. 
After $300 \mathrm{~m}$ along this traverse the south wall was abandoned and ALVIN began a traverse to the north wall of the valley. The maximum depth of the valley floor recorded during the crossing was $3421 \mathrm{~m}$. In addition to the ubiquitous biota observed throughout the dive, a concentration of red holothurians floating above the sediment surface were observed during the transect. An outcrop of mudstone marked the north wall.

ALVIN proceeded east along the north wall where outcrops with varying stages of erosion were observed. A common occurrence along this traverse of the north wall were concentrations of semi-circular white anemones. Clam shells were observed at $3411 \mathrm{~m} \mathrm{depth}$. After 1 hour on this traverse we began to proceed up an east-facing slope. More clam shells were observed at this time. At a depth of $3382 \mathrm{~m}$, a concentration of rounded black rocks were observed protruding from the slope. One of these rocks was recovered from this site (Station 5). ALVIN continued upslope and passed over a series of mudstone outcrops. The final core sample (Station 6) was taken at a depth of $3334 \mathrm{~m}$ at the top of an extensive outcrop of jointed mudstone. After this station the dive terminated at 2:50 p.m.

Dive 2831

Observers: H. G. Greene and C. Baxter

Pilot: Paul Tibbets

This dive was made in the lower part of the large incised meander cut in to the shelf by erosion in Monterey canyon (Figure 1). The objective was to observe sedimentary processes in the canyon axis and to sample the stratigraphic sequence on the northeastern wall of the canyon here. This dive started at a water depth of $1218 \mathrm{~m}$ and ended at a depth of $828 \mathrm{~m}$. The canyon walls are very steep and the canyon axis is narrow at this location (Figure 10). Visibility was poor, less than $1 \mathrm{~m}$, and a strong down-canyon current $(\sim 1 / 2 \mathrm{knot})$ was encountered. Large (4-6 $\mathrm{cm}$ high, meters long) ripple marks were present and were oriented perpendicular to the current flow, which appeared to be from a direction of $030^{\circ}$ magnetic. The tremendous amount of biomass in the water column restricted full observation of these ripples.

In $1217 \mathrm{~m}$ of water, a core tube was pushed in to the coarse sand bottom. The core penetrated about $20 \mathrm{~cm}$ of the sand before it hit a hard layer. Unfortunately, the sample washed out, and no recovery was made. From observation through the port, the sediment appeared to be a white to gray, arkosic, well sorted, medium to coarse grained sand.

From the site of the attempted coring, we obliquely traversed the canyon floor generally travelling north in an attempt to reach the northeastern wall. Throughout most of this traverse, we had only occassional glimpses of the bottom because of poor visibility. Where the bottom was seen, ripple marks dominated the seafloor morphology. In many areas a light brown, very fine organic flocculant material appeared to be concentrated in the troughs of the ripples, while portions of this flocculant material appeared to be swept across the crest of the ripples by the strong current.

At $1212 \mathrm{~m}$ water depth, two separate and distinct sets of ripple marks were observed. The major set was oriented east-west and appeared to be superimposed upon cross-ripples trending $030^{\circ}-040^{\circ}$ magnetic. Here the current is coming up canyon from the south.

At $1210 \mathrm{~m}$ depth we encountered a hard, organic-encrusted boulder. We attempted to obtain a sample but were unable to do so because of the roundness and hardness of the rock. We continued on a course of about $050^{\circ}$ magnetic and encountered more boulders at $1206 \mathrm{~m}$. Some boulders were large and all had a granular texture but were covered with organisms; we believe they were granite and that ALVIN was near the eastern granite wall. 
At $1204 \mathrm{~m}$, travelling almost due east in very poor visibility, we observed barcan-type ripples in fine grained sediments. At $1202 \mathrm{~m}$, ALVIN heading was $040^{\circ}$, parallel to linear ripple marks. ALVIN's speed increased markedly here apparently due to a current from the south, up-canyon.

At about $1140 \mathrm{~m}$, ALVIN encountered a steep rock wall, rich with a very diverse community of benthic life. The steep, irregular surface was coated with fine sand and silt, had a granular texture diagnostic of granite and was fractured. We attempted to sample rock, but a strong (over $3 / 4$ knots) up-canyon current swept ALVIN rapidly up canyon.

A push core was obtained in a mud slope at $1125 \mathrm{~m}$. After taking the core, we continued along a traverse on $025^{\circ}$ magnetic. We encountered a strong ( $~ 3 / 4$ knot) up-canyon current again 4 minutes later in $1122 \mathrm{~m}$ water depth.

We attempted to recover a loose man-made float at $1186 \mathrm{~m}$ in what appeared to be a debris chute. Here, small cobble-and pebble-size angular chunks of rock were interspersed with fine grained sediment, all organically coated. The current swept ALVIN away from the out-crop and we were unable to recover a sample.

At $1098 \mathrm{~m}$, in very poor visibility and a strong current we decided to rise above bottom and move upslope out of the region of the canyon axis. We then encountered a 1-knot current where a non-bioturbated sloping bottom was observed to be composed of shells, shell fragments, pebbles and gravels.

At $1083 \mathrm{~m}$, ALVIN stopped at the base of a cliff. Pebbles, cobbles, and boulders were scattered about and interspersed with shell fragments, all probably transported. Evidence of winnowing and current scour was observed. The area was populated with flounders and other bottom fish. Further along, a sample of what appeared to be Monterey mudstone was collected in $1079 \mathrm{~m}$ of water.

At $1073 \mathrm{~m}, \mathrm{ALVIN}$ was heading upslope at $092^{\circ}$ but probably making good $030^{\circ}$ because of being set by a strong, up-canyon current. The slope was composed of bioturbated mud with many pebbles and cobbles of mudstone (?). At $1067 \mathrm{~m}$, we travelled upslope at $110^{\circ}$ magnetic along a highly bioturbated bottom with many holes, worm tubes, and generally a gentle, hummocky topography.

At $1055 \mathrm{~m}$, ALVIN turned more northerly in hopes of encountering outcrops that could be sampled. At $1072 \mathrm{~m}$, we encountered another cliff, however, the northward current again swept ALVIN sideways along a shell-scattered mud slope with a few boulders at the base of the cliff.

At $990 \mathrm{~m}$, we rose slowly, still with poor visibility and were carried along northward by the current. A cliff was seen on sonar at $854 \mathrm{~m}$, and ALVIN headed toward it. The water column was full of shells and shell fragments dropping to the bottom. It appears as if shells were being swept from the shelf above, over the shelf edge and down on to the slope by the strong northward flowing current.

At $861 \mathrm{~m}$, we encountered about a 1-knot current, and ALVIN was swept along a bioturbated, mud bottom with many sea pens. Boulders and cobbles were scattered about. Benthic biota on bottom were either bent over flat, if anchored, or were tumbling across the bottom with shell fragments if not anchored. Small fish facing in to the current struggled to keep their position. We observed distinct scour depressions around boulders. Pilot estimated current to be 1 to $1-1 / 4$ knots. 
At $850 \mathrm{~m}$, ALVIN moved slowly upslope. We observed a holothurian wrapped around a rock; lots of flounder present; encountered a beautiful rock cliff face at $845 \mathrm{~m}$. Obtained a chunk of what looks like Monterey formation at $843 \mathrm{~m}$.

At $837 \mathrm{~m}, \mathrm{ALVIN}$ approached the base of an outcrop suspected to be composed of Monterey mudstone. A rubble field littered with large angular chunks of rocks was found at the base of the slope. Many boulders, all heavily coated with organic matter, were observed interspersed with sea pens, sea fans, and sponges. A thinly silt-coated wall covered with a colorful benthic community extended above the rubble base. Many flounder and rock fish were observed. Several rock samples were collected in this area; all were Monterey mudstone.

At $839 \mathrm{~m}$, ALVIN rose above the outcrop and promptly encountered a strong current. Evidently, ALVIN was in the lee of the outcrop where current was reduced and, therefore, samples could be collected. Because of the strong current and continuous poor visibility it was decided to end the dive at 1246 in $828 \mathrm{~m}$ depth.

In summary, this dive (primarily) examined the southern wall of Monterey canyon in the vicinity of the lower bend of the structural meander cut into the upper slope. Poor visibility and strong currents throughout most of the dive prevented complete sampling and good observation. The coarsely rippled medium- to coarse-grained sands encountered in the canyon axis indicate a strong current regime and sand bedload transport. The narrowness and steep walls of the meander evidently constrict current flow here and allow for rapid, concentrated transport of sediment down canyon. Along the eastern side of the canyon the lower wall is composed of granites as observed from ALVIN, and the upper wall is composed of Monterey siltstone as determined from sampling.

\section{Summary of Camera Transects}

The photographic coverage of the Monterey canyon and fan, and of the adjacent continental slope and upper continental rise, consisted of seven camera transects (no pictures obtained for one) that were run during the nights and covered more than $80 \mathrm{~km}$ of seafloor (Figure 2). The camera was towed on a sled along the canyon floor (tow no. 3), the fan valley thalweg (no. 1), the large "horseshoe" meander, terraces on the inside of the meander bend, levee crests, a gap in the levee crest, a large rotational slump (no. 2), erosional chutes on the lower continental slope, a debris-flow apron, and a field of abyssal mud waves (nos. 4, 5, and 6). The sea-floor was photographed every $15 \mathrm{sec}$ with the camera aligned for an oblique view at an altitude of 0.5 $\mathrm{m}$. More than $6,00035 \mathrm{~mm}$ color pictures were obtained. Camera transects of the Monterey canyon and fan are here described in numerical order.

Camera Run No. 1. This traverse is along thalweg of Monterey fan valley at a depth of $3500 \mathrm{~m}$ southwest of its confluence with Ascension canyon (Figure 2). It extends along the thalweg to an approximate depth of $3600 \mathrm{~m}$.

At the beginning of the run the sea-floor is flat, with no microtopography. The sediment appears consolidated, with a veneer of flocculent material, and is covered by hydroid growths. Most of the run, however, exhibits lag deposits and a complex microtopography we describe as disrupted terrain, partly covered with mud, where the action of turbidity flows and more competent mass-wasting events is evidenced. Rounded pebbles, boulders and angular rocks were photographed that are evidence of turbidity current events and/or debris flows. Small mounds occur in the area of the disrupted terrian. Xenophyphore, a protozoan that aggregates mud into small balls, is present along this run; holothurian faunal asemblages are less abundant here than 
on the other camera traverses.

The last segment of the run shows very flat consolidated-appearing sediments with a thin coat of loose muds. The substrate is pitted but has no other microtopography. Filter-feeder holothurians that prefer harder substrates and currents are present. This smooth muddy bottom and the observed fauna are suggestive of a tranquil but current-swept environment.

Camera Run No. 2. The photographic coverage of this run began on the levee east of the Monterey valley meander bend at a depth of $3300 \mathrm{~m}$. The camera descended into the fan valley thalweg at $3400 \mathrm{~m}$ depth, and climbed the stepped terraces on the inside of the large meander, descended into the thalweg at the apex of the meander bend, climbed through a steep vertical mudstone wall through a breach in the outside levee into the Monterey-East fan valley where it descended through a chute and a crescent shaped depression (Figure 2).

In the region of the meander, the substrate is again consolidated-appearing muds with a thin cover of bioturbated muds. More consolidated strata crop out on the channel walls (and terraces?) where erosional processes have occurred. Where the loose sediment is more abundant, burrowing organisms have sculpted the terrain in to microtopographic mounds, and small pits give evidence of some scouring of the seafloor. Another indication of active processes is found in the presence of filter-feeding holothurians and medusas that are known to prefer currents.

On the walls and floor of the valley, abundant seeps were sighted. A few clams, identified as Solemaya, which have been previously found in the Oregon Subduction Zone, are the most prevalent species at this seep. As the camera descended to the thalweg at the center of the meander bend, photos were obtained showing that the faunal assemblage is dominated by the holothurian Peniagone, and that the channel bed is covered by fecal pellets, giving the sediment a stringy appearance.

The Monterey-East fan valley appears almost undisturbed by currents or in termittent flow. It is characterized by microtopography in the form of mounds, hydroid growths and dead tube worms; it has a thicker surficial cover of flocculant muds, and a generally disaggregated appearance because of the abundance of fecal pellets. A crescent shaped depression at the end of the camera run exhibits roughly corrugated bedforms or ridges of a mud-draped broken terrain.

Camera Run No. 3. This traverse was initiated in the thalweg of the lower Monterey canyon at a depth of $2940 \mathrm{~m}$. The run proceeded downcanyon in to the upper Monterey fan valley to a depth of $3100 \mathrm{~m}$.

The substrate is composed of consolidated-appearing muds with a thin, loosely packed, and muddy surficial cover. The terrain is nearly flat with only small waves or undulations. Isolated patches of the underlying consolidated-appearing muds are seen throughout the camera transect, and they are suggestive of current scouring. Burrowing organisms sculpt the sea-floor into small depressions, such that the lower canyon and upper fan terrain look pock-marked.

Evidence for sediment failure and erosion in a headward direction is found in the lower Monterey canyon where the camera descended across a rocky escarpment at a depth of $2950 \mathrm{~m}$. Large boulders, partly buried with mud and covered with hydroid growths, are found below the steep ledge. These boulders have served as obstacles behind which sediments and broken shells have accumulated, and have also served as substrates for anemones and sponges that prefer hard substrates.

Generally throughout the camera run, there is evidence, from light back-scatter, of abundant suspended fine-grained sedimentary and/or organic particles. Benthic life is dominated by 
holothurians, and iollowed in importance by brittle stars. Other organisms such as anemones, sponges, corals, sea pens, worms, urchins, gastropods, crabs, and sea spiders are common.

A large seep community was sighted at approximately $3020 \mathrm{~m}$ (Figure 11). The community consisted of approximately 200 Calyptogena clams concentrated at the edge of an ovalshaped region, approximately $3 \mathrm{~m}$ in length. The surficial unconsolidated sedimentary cover in the center of the oval and in close proximity to the seep community is a mud of darker color than the sediments nearby. Smaller seep communities were recorded in several photographs throughout the upper fan.

Camera Runs No. 4, 5, and 6 . These camera tows form a north to south transect along the lower slope, at a depth of $2500 \mathrm{~m}$, and a westward traverse on to the fan. The three tows were made purposely along the same track, within navigational and positioning accuracies. Photographs on the lower slope show a tranquil deep-sea floor, with mounds, burrows, and tracks virtually undisturbed by currents except for smoothed and slightly undulating terrain in some locations that maybe caused by current action. This area is covered with mud and carpeted by brittle stars. Other organisms found on the slope are holothurians, sea pens, anemones, urchins, sea whips, worms, crabs, sea spiders, gastropods, and star fishes.

A field of bedforms that appear as mud waves in acoustic-reflection records is crossed on tow no. 6 on the fan adjacent to the base of the slope. These mud waves have amplitudes of up to $15 \mathrm{~m}$, and are covered with fields of sea pens. Sea pens, which feed on small organisms, require moderate to strong bottom currents.

\section{Observations and Preliminary Interpretations}

1) The high organic content of the sediments of the valley floor and walls is suggested by a profusion of benthic biota including seep colonies. In general, benthic faunas are dominated by holothurians.

2) Seep communities are ubiquious to the Monterey fan and Ascension fan valleys. Apparently ephemeral in nature, some expired communities were found consisting mostly of empty clams shells, and some live and varied communities were found with clams and tube worms being the most distinctive and populous inhabitants. The organisms appear to be feeding on organic-rich fluids diffusing from organic material in the subsurface. There are two possible sources for such seep fluids: (1) they may be venting from organic material in fan sediments along bedding planes to canyon wall outcrop; or (2) they may result from vertical leakage from valley-floor sediments caused by overpressure from more recent material deposited on the valley floor.

3) The deepest region of the thalweg on the Monterey fan valley southwest of its confluence with Ascension canyon appears to be a tranquil environment but with evidence of weak currents (dive 2124), high sedimentation rates, and abundant benthic life. This calm setting is intermittently disrupted by local mass-wasting events as the erosionally oversteepened valley wall collapses.

4) Highly flocculant and bioturbated muds, easily stirred up by ALVIN's downward thrusters, dominated the valley floor, and no evidence of material coarser than muds were evident, although at shallower depths in the canyon, e.g., $1970 \mathrm{~m}$ on dive 2128 and $1200 \mathrm{~m}$ on dive 2131 , a rippled sandy bottom was observed.

5) High levels of turbidity, which limit visibility to about 1 meter, exist intermittently in 
the valley floor; however, turbidity was not excessive and visibility was adequate for navigation most of the time.

6) The Monterey-East fan valley appears practically undisturbed by currents or intermittent flows.

7) In places, the lowermost valley walls consist of vertical erosional scarps $5-10 \mathrm{~m}$ high with horizon tally layered outcropping strata.

8) In Ascension valley, just north of the confluence with Monterey valley, a distinctive type of mass wasting was observed. The north wall consists of vertically jointed rock that forms angular chutes down which blocks of the rock wall have slid.

9) At about $1970 \mathrm{~m}$ depth, at the confluence with Carmel Canyon, Monterey canyon shows evidence of high current velocities, with a smoothed and rippled sand-mud bottom, with rocks scoured clean of sediment and biota. Also, man-made debris, wood, and a recently introduced tree trunk were observed at this location.

10) Outside the canyon-valley walls, the lower-slope environment appears calm with smooth and undulating terrain indicative of some current activity, with brittle stars the dominant benthic organism.

Acknowledgements

The six ALVIN dives in Monterey Canyon discussed in this report were funded by the NOAA Office of Undersea Research. We are especially grateful to David Duane, the Program Manager, who made us aware of the opportunities for ALVIN dives in the canyon. He and the ALVIN Review Panel encouraged several groups to make a conbined dive program. We are also grateful to Chris Harrold of Monterey Bay Aquarium and Emory Kristof and their colleagues of Natural Geographic, who agreed to combine their programs with ours. This cruise was truly an example of "the whole being greater than the sum of its parts." Finally, we thank the ALVIN group, and Officers and crew of the AII for all their efforts. 


\section{REFERENCES}

Atwater, T., 1970, Implications of plate tectonics for the Cenozoic tectonic evolution of western North America: Geological Society of America Bulletin, v. 81, pp. 3513-3536.

Brunner, C. A., and Normark, W. R., 1985, Biostratigraphic implications for turbidite depositional processes on the Monterey deep-sea fan, central California: Journal Sedimentary Petrology, v. 55, p. 495-505.

Eittreim, S.L., Embley, R. W., Normark, W. R., 1983, Monterey sea-valley meander revisited (abs.): Amer. Geophys. Union, Transactions, v. 64,, p. 730.

EEZ-SCAN 84 Scientific Staff, 1986, Atlas of the Exclusive Economic Zone, western conterminous United States: U.S. Geological Survey Miscellaneous Investigation Series, I-1792, scale 1:500,000, 1552 p. text.

Greene, H.G., 1977, Geology of the Monterey Bay region: U.S. Geological Survey Open-File Report No. 77-718, 347 p., 9 plates.

Normark, W.R., 1970, Channel piracy on Monterey deep-sea fan: Deep-Sea Research, v. 17, p. 837-846.

Normark, W.R., Gutmacher, C.E., Chase, T.E., and Wilde, P., 1985, Monterey Fan, Pacific Ocean: in Submarine Fans and Related Turbidite Systems, ed. by Bouma, A.H., Barnes, N.E., and Normark, W.R., Springer-Verlag, New York, p. 79-86.

Shepard, F. P. 1966, Meander in valley crossing a deep-ocean fan: Science, v. 154, p. 385-386.

Shepard, F. P., 1973, Submarine Geology: Harper and Row, New York, 517 p.

Shepard, F.P., and Dill, R.F., 1966, Submarine canyons and other sea valleys: Rand McNally, Chicago, $381 \mathrm{p}$.

Wilde, P., Normark, W. R., and Chase, T. E., 1978, Channel sands and petroleum potential of Monterey deep-sea fan, California: American Association of Petroleum Geologists Bulletin, v. 62 , p. 967-983. 


\section{CAPTIONS}

Figure 1. Dive locations. Three of the five dives discussed in this report are in the Monterey Meander area shown in detail in Figure 2. Note that the contours of this regional-scale map are seriously in error in the region of the Monterey Meander (compare to Figure 2).

Figure 2. Seabeam-produced bathymetry (20-m contour interval) in the Monterey Meander area from a 1983 survey of NOAA ship SURVEYOR. ALVIN dive locations (sub release locations) and bottom camera-sled tows are shown.

Figure 3. ALVIN estimated bottom track and sketch of observed features and sample locations on dive 2124.

Figure 4. ALVIN estimated bottom track and sketch of observed bottom features, dive 2127.

Figure 5. ALVIN color camera photograph of base of west wall of Monterey fanvalley, showing the shape boundary between soft valley-floor muds and the indurated, stratified wall outcrops, thickly populated with organisms. Width across photograph approximately $2 \mathrm{~m}$.

Figure 6. ALVIN estimated bottom track and sketch of observed bottom features, dive 2128.

Figure 7. ALVIN estimated bottom track, sketch of bottom observations and sample locations, dive 2130 .

Figure 8. Hand-held photograph of area of tube worms, with the appearance of "tall grass". Width across photograph approximately $2 \mathrm{~m}$. Dive 2130 .

Figure 9. Deck photograph of live clam from seep area on dive 2130.

Figure 10. ALVIN estimated bottom track and sketch of bottom observations, dive 2131.

Figure 11. Photograph from camera tow sled, run 3, axial Monterey fan valley, showing seep clam colony. Approximately $2 \mathrm{~m}$ across picture in foreground. 


\section{TABLE I - SAMPLE LIST--MONTEREY CANYON DIVE SERIES OCTOBER 21-30, 1988}

DIVE NO

2123

2124

2125

2126

2127
STATION NO.

1

Clam shells

$1 \mathrm{C}$

$2 \mathrm{R}$

$3 \mathrm{C}$

$4 \mathrm{C}$

$5 \mathrm{~N}$

$6 \mathrm{R}$

$7 \mathrm{C}$

$8 \mathrm{R}$

$9 \mathrm{C}$

Mud

Core

Mudstone

Mudstone

Mudstone

Core

Mud

Core

Rock

Anemones

Rock

(0957)

2

(1030)

Rock

3

(1970)

Rock

$1 \mathrm{~A}$

$1 \mathrm{~B}$

Core

Core

1C Core

2

Core

2

Mud

2

Mud

2 Clams
DEPTH

COMMENTS

$3600+\quad$ In deepest part of Monterey

valley, southwest of dive 2124

Nothing recovered

Small plastic bag

About $2 \mathrm{~cm}$ of clay

1 plastic bag

2 full ziplock bags

1 ziplock bag

Almost full $(30 \mathrm{~cm}$ ?)

a) small sample in ziplock bag

b) large plastic bag

Almost full

ca. $3000 \mathrm{~m}$

Monterey Canyon, north wall

1987

1970

1970

3482

3482

3482

3445

3445

3445

3445

Granodiorite?

Collected from large boulder field

Metavolcanic?

Collected in place from steep cliff

Metamorphic--

Collected from fracture in steep cliff

$28 \mathrm{~cm}$

$15 \mathrm{~cm}$

$7 \mathrm{~cm}$

All three cores taken in thalweg of Monterey Sea Valley axis at greatest depth, $10 \mathrm{~m}$ from western wall

$18 \mathrm{~cm}$--Taken $37 \mathrm{~m}$ up west wall on talus-debris slope. In clam colony at site of gray-black discoloration of sediments

Mud picked up in net with clams-ziplock garbage bags-Refrigerated

Mud picked up in net with clams-2 ziplock bags--frozen

Live specimens-one intact

put in formalin

East wall, Monterey canyon 
TABLE I - CONTINUED

DIVE NO. STATION NO. SAMPLE TYPE DEPTH

COMMENTS

2129

2130

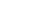

\begin{tabular}{|c|c|}
\hline $\begin{array}{r}(1030) \\
2 \mathrm{a} \\
(1037)\end{array}$ & Core \\
\hline $2 b$ & Mudstone \\
\hline 3 & Core \\
\hline & Core \\
\hline 3 & Clams \\
\hline 3 & Mud \\
\hline $\begin{array}{r}4 \\
(1248)\end{array}$ & Core \\
\hline $\begin{array}{c}5 \\
(1439)\end{array}$ & Rock \\
\hline $\begin{array}{c}6 \\
(1452)\end{array}$ & Core \\
\hline
\end{tabular}

1670 Sandstone?

Collected on west wall of Carmel Canyon

1691

Granite-Collected from sediments in channel of Carmel Canyon

Collected from kelp hold-fasts in center of Carmel Canyon

3397 Base of north wall, Ascension valley

$3391 \quad$ About $12 \mathrm{~cm}$

$3391 \quad 3$ Ziplock bags

$3405 \quad$ Under live clams

3405 Core with tube worm-taken a few meters from live clam site 34052 live clams-one whole one put in formalin; one whole one and broken pieces--frozen

3405 Mud sampled with clams in 2 large ziplock bags

3384 On hard outcrop on south wall; $24 \mathrm{~cm}$

3382 Rounded boulder from "water"fall" slope

$3334 \quad 13 \mathrm{~cm}$ 


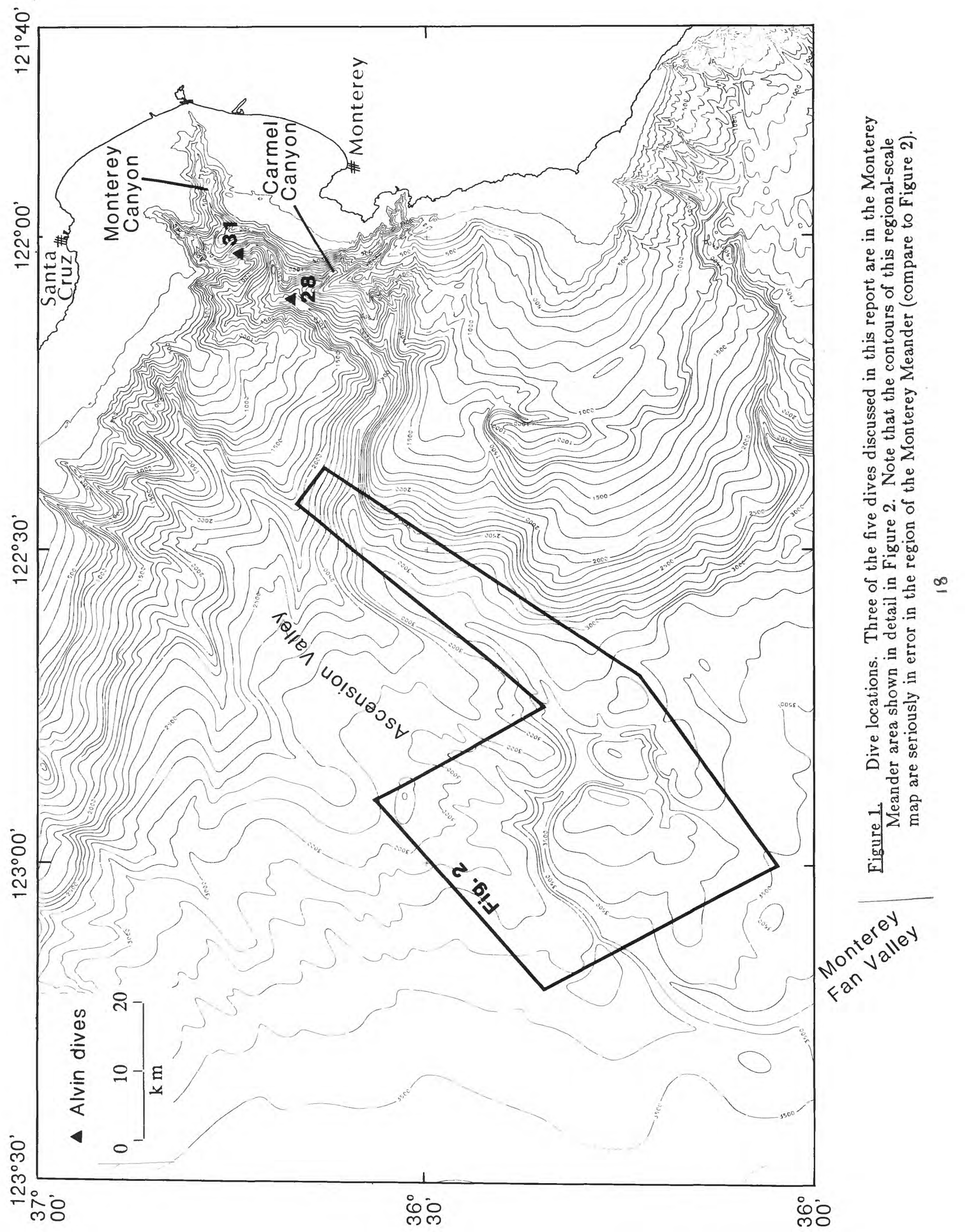




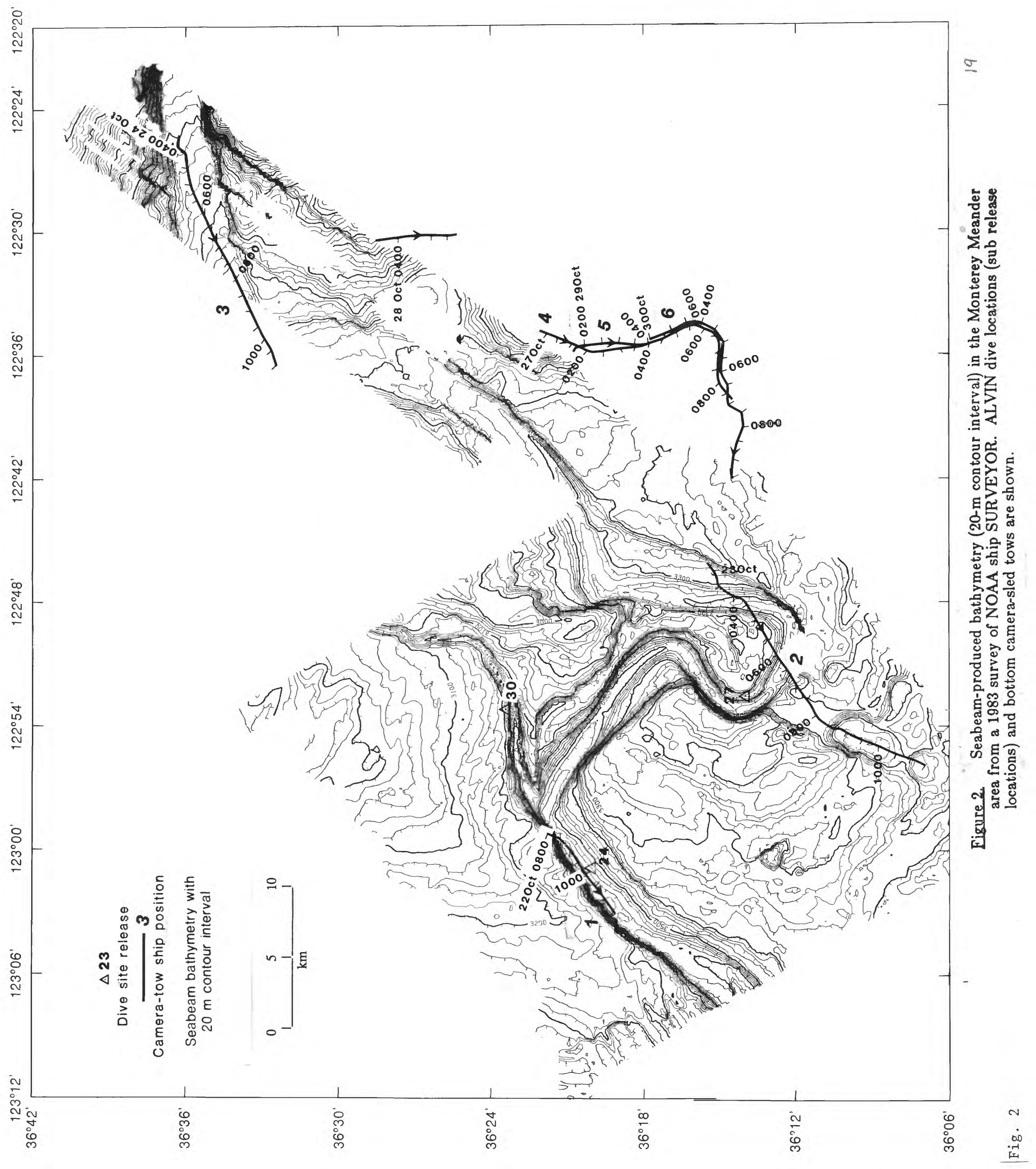




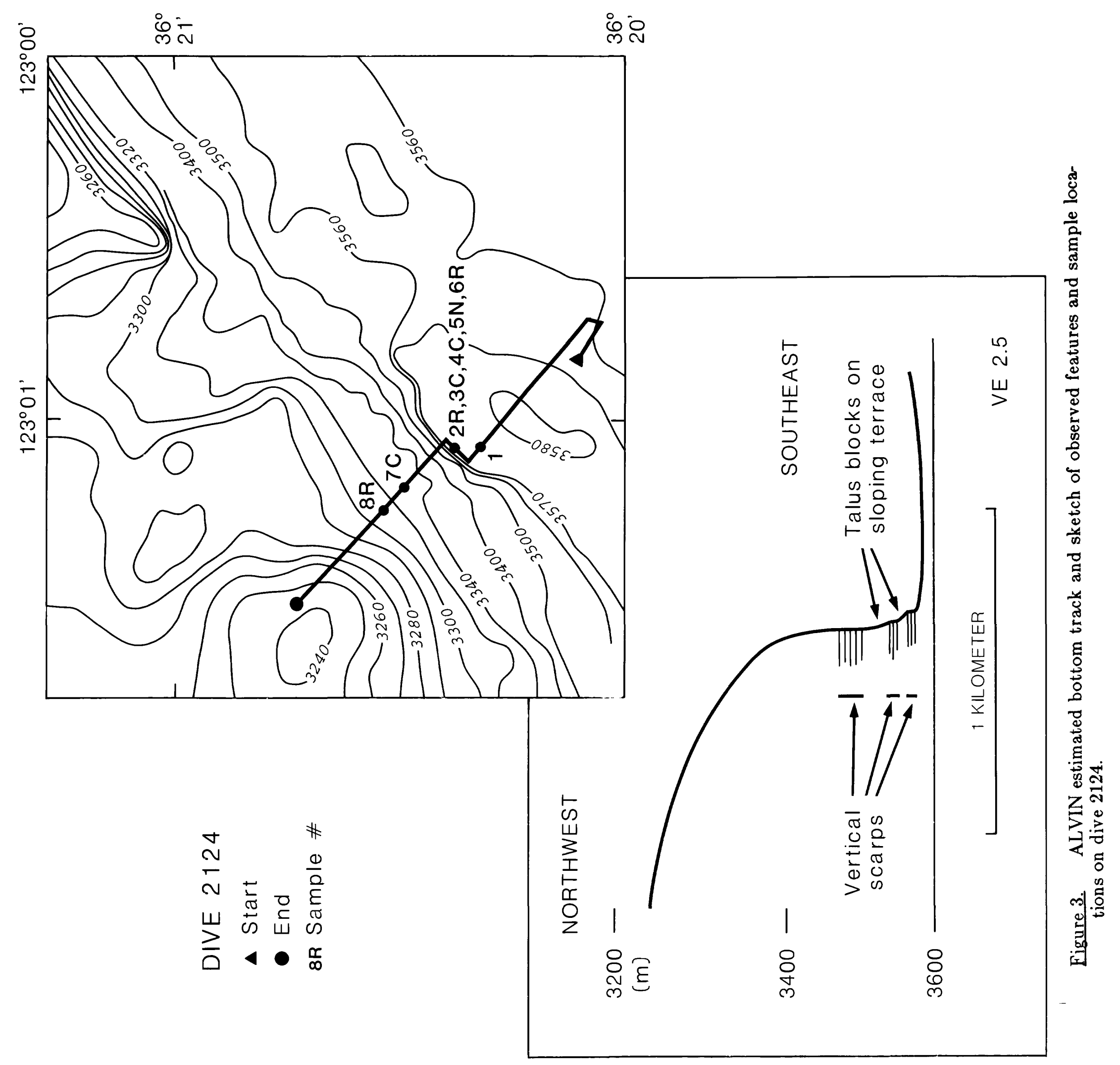

Fig. 3 


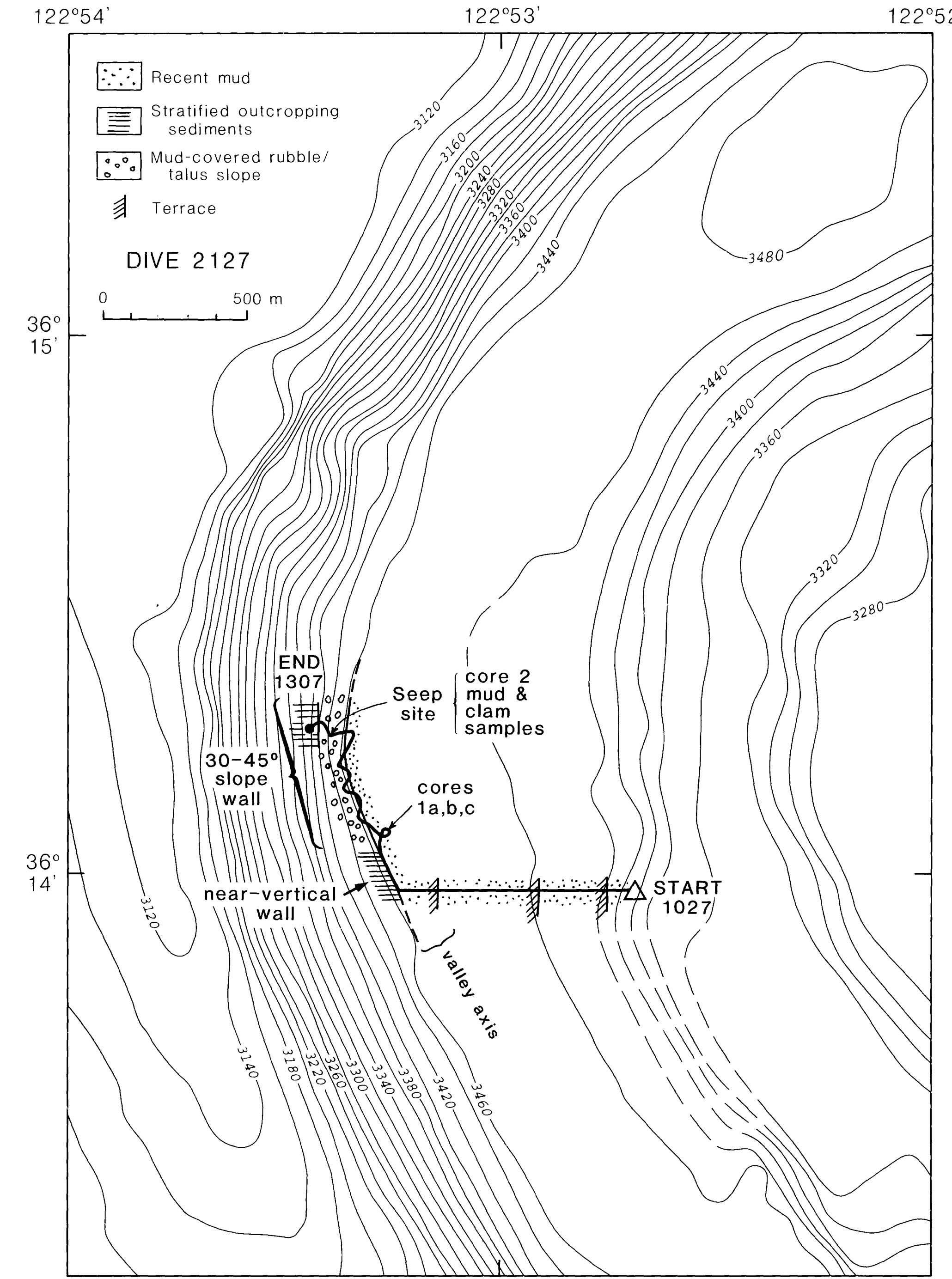

.

Eigure 4. ALVIN estimated bottom track and aketch of observed bottom features, dive 2127. 


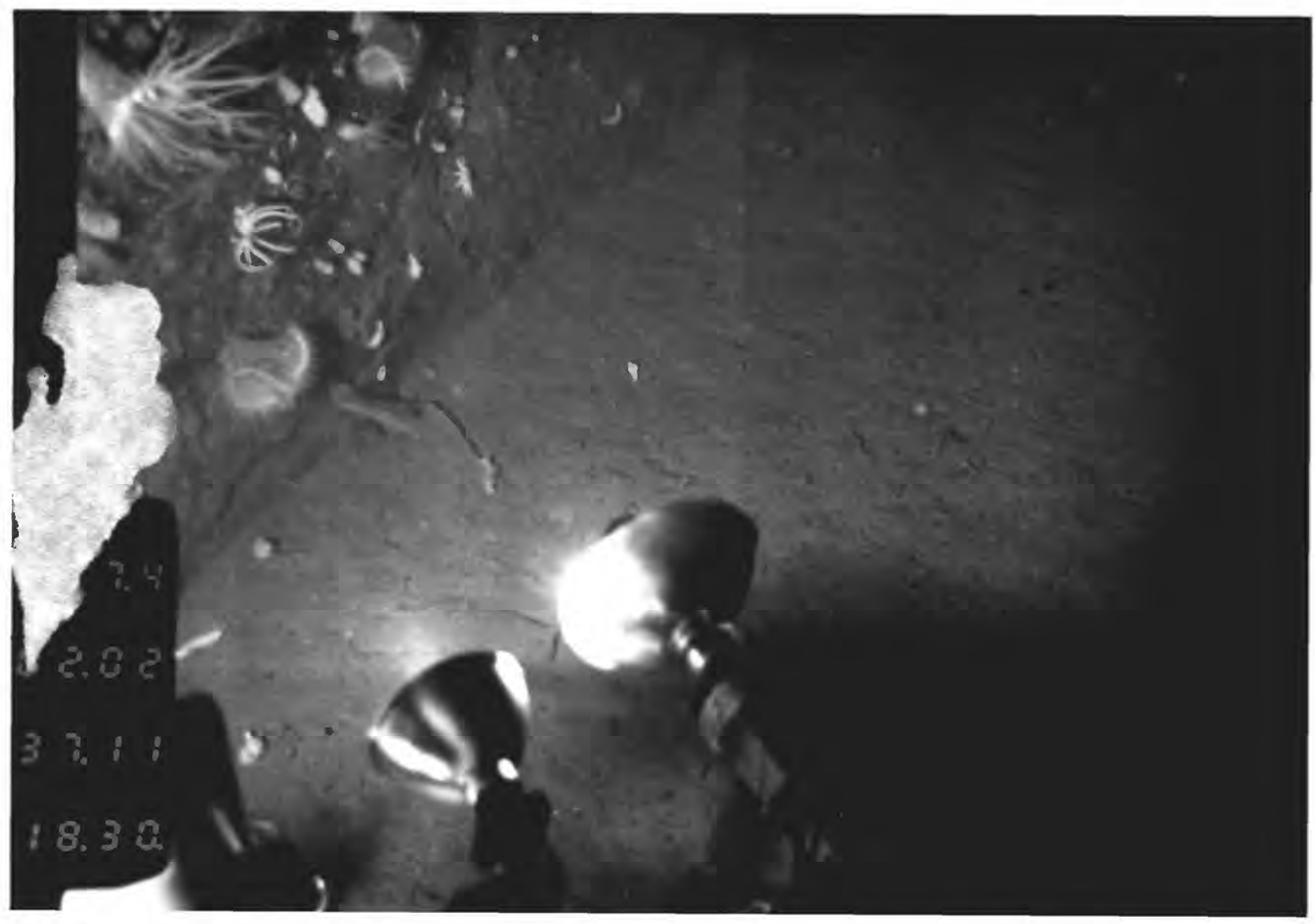

Figure 5. ALVIN color camera photograph of base of west wall of Monterey fanvalley, showing the share boundary between soft valley-floor muds and the indurated, stratified wall outcrops, thickly populated with organisms. Width across photograph approximately $2 \mathrm{~m}$. 


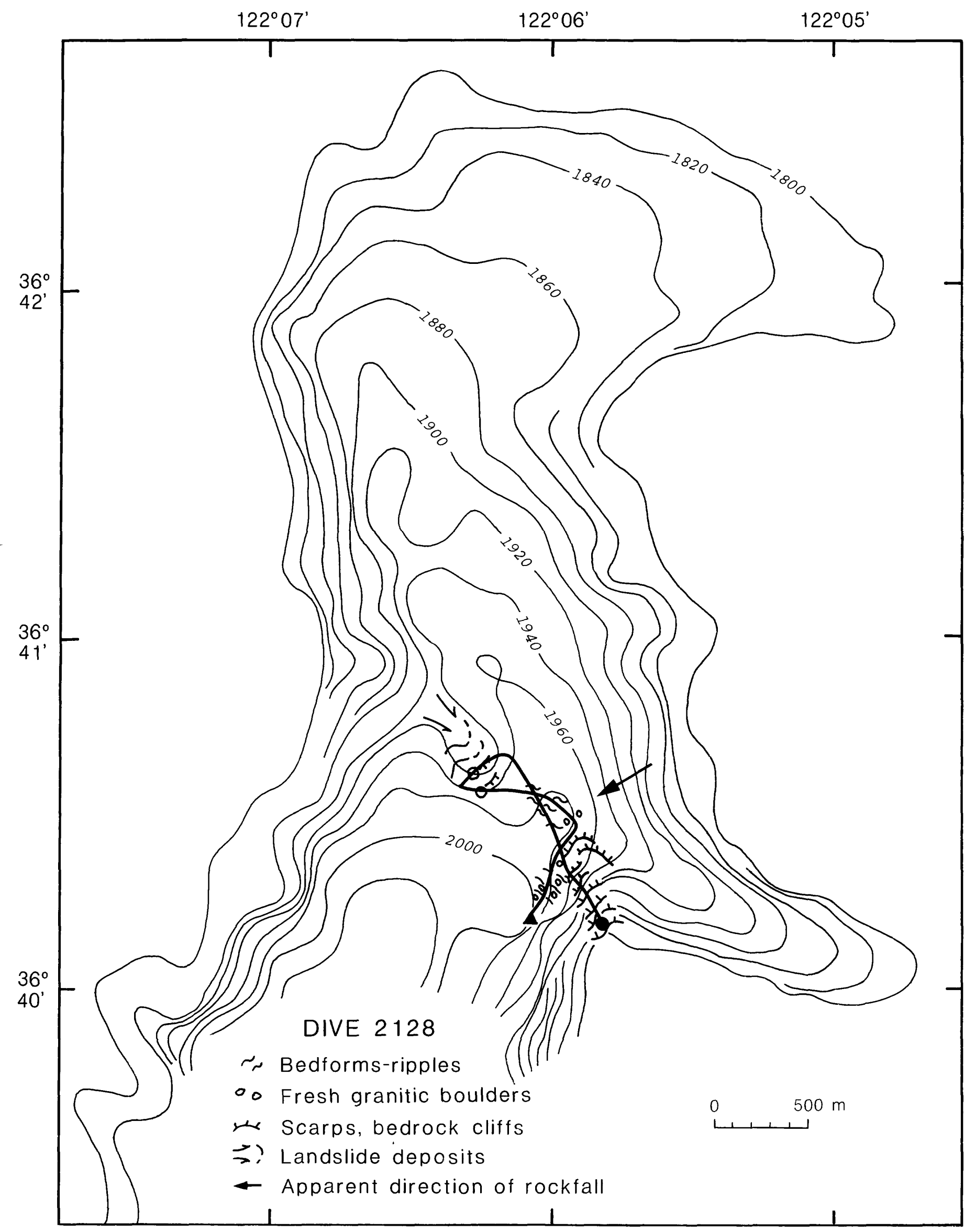

Figure 6. ALVIN estimated bottom track and sketch of observed bottom features, dive 2128. 


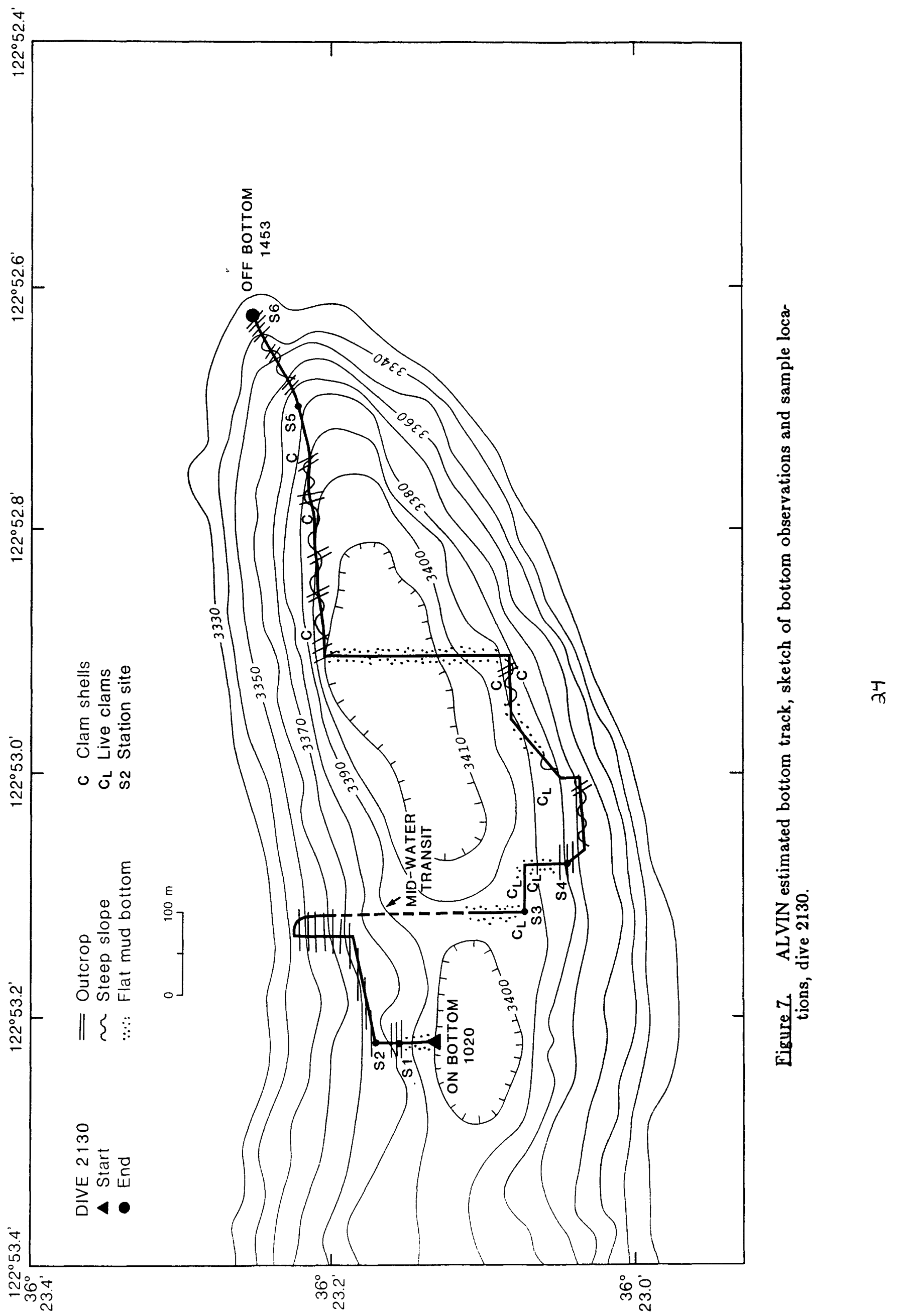




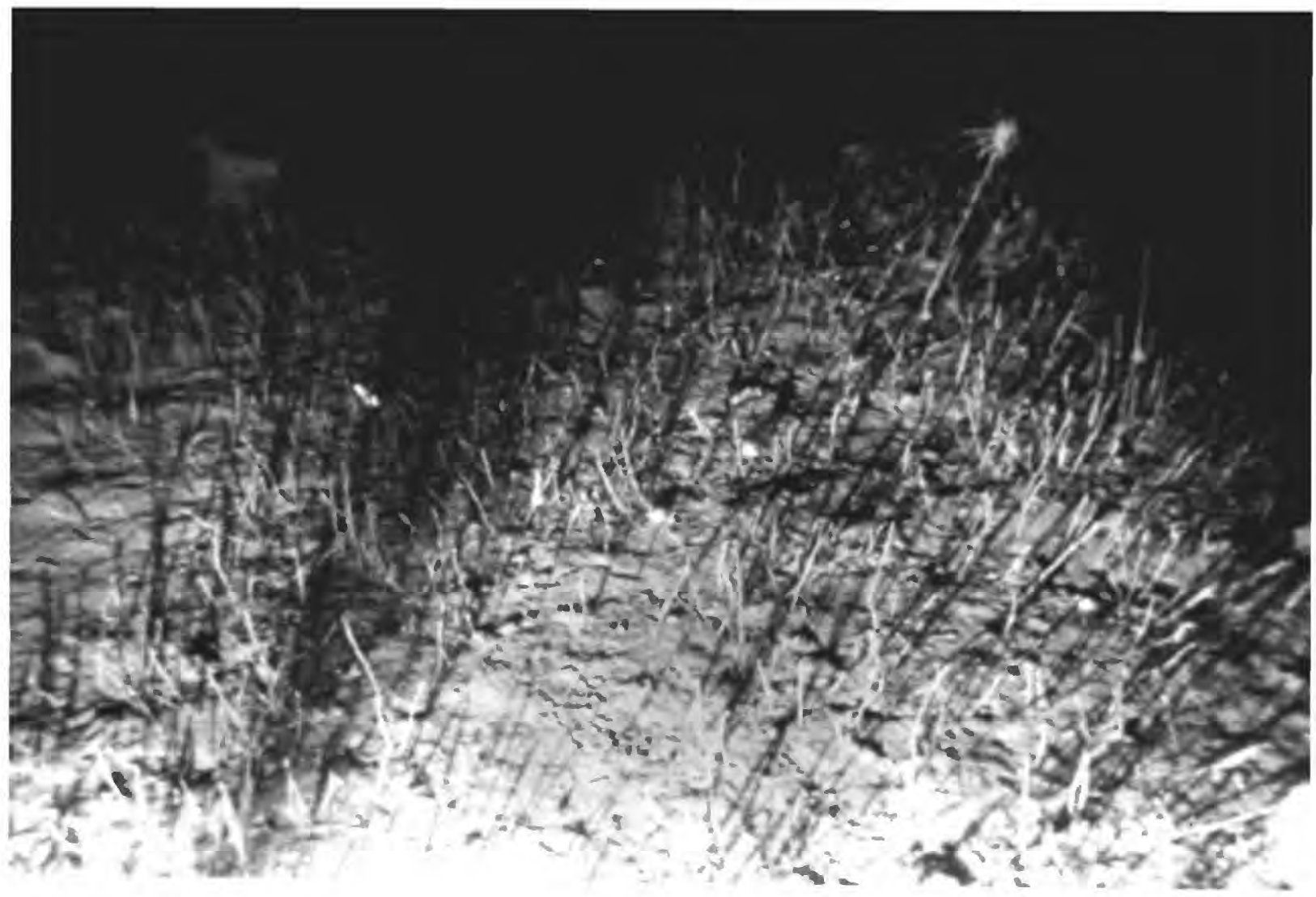

Figure 8. Hand-held photograph of area of tube worms, with the appearance of "tall grass". Width across photograph approximately $2 \mathrm{~m}$. Dive 2130 . 


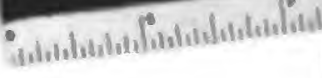

DIVE 2127

MONTEREY

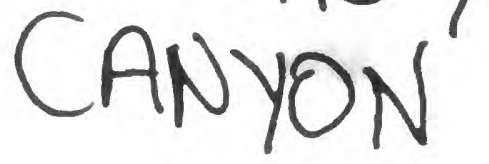

Figure 9. Deck photograph of live clam from seep area on dive 2130.

24

Fig. 9 


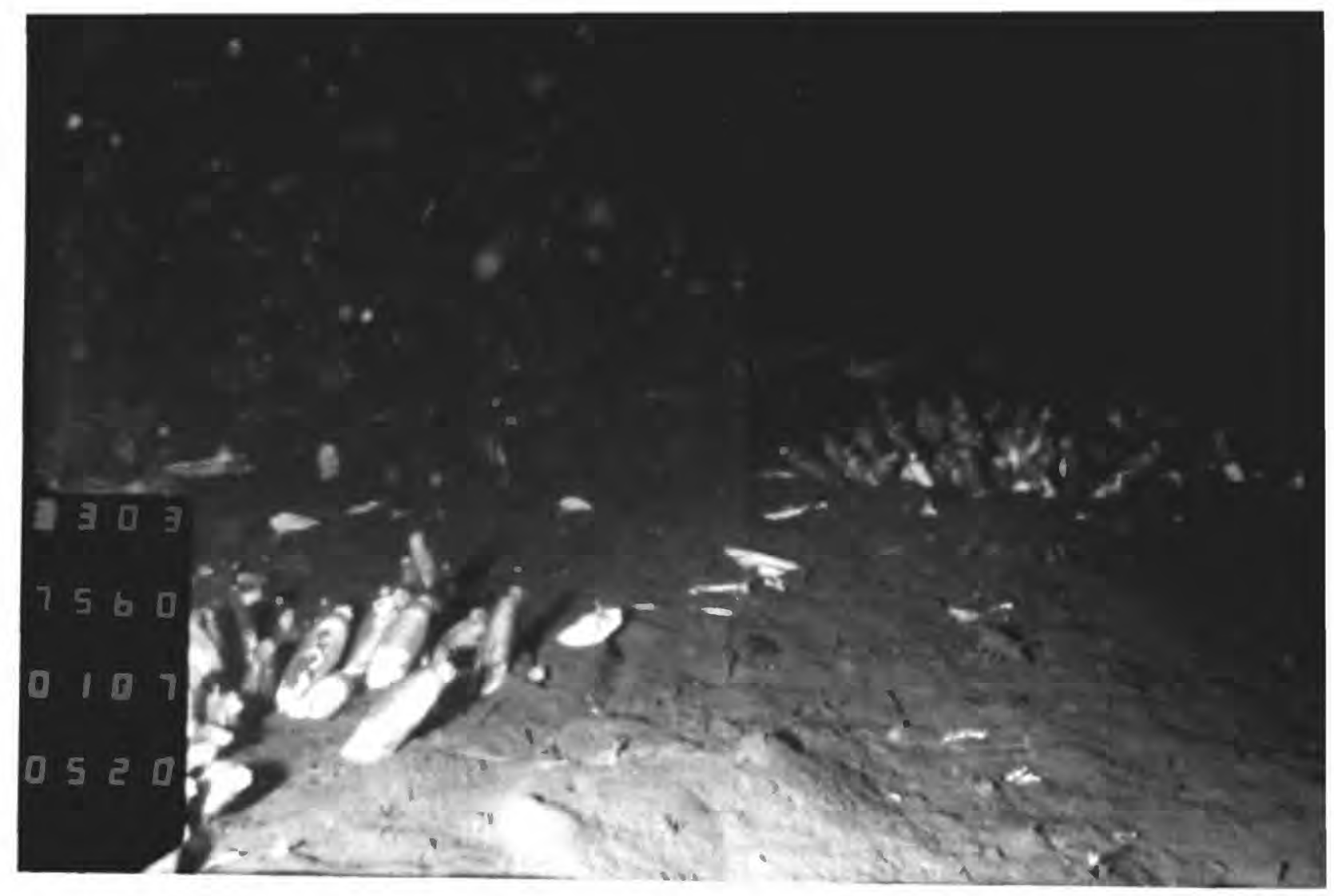

Figure 11. Photograph from camera tow sled, run 3, axial Monterey fan valley, showing seep clam colony. Approximately $2 \mathrm{~m}$ across picture in foreground. 